\title{
Pergeseran Model Bisnis Media dan Etika Media: Era Integrasi Informasi, Redaksi, Teknologi, dan Proses Jurnalistik
}

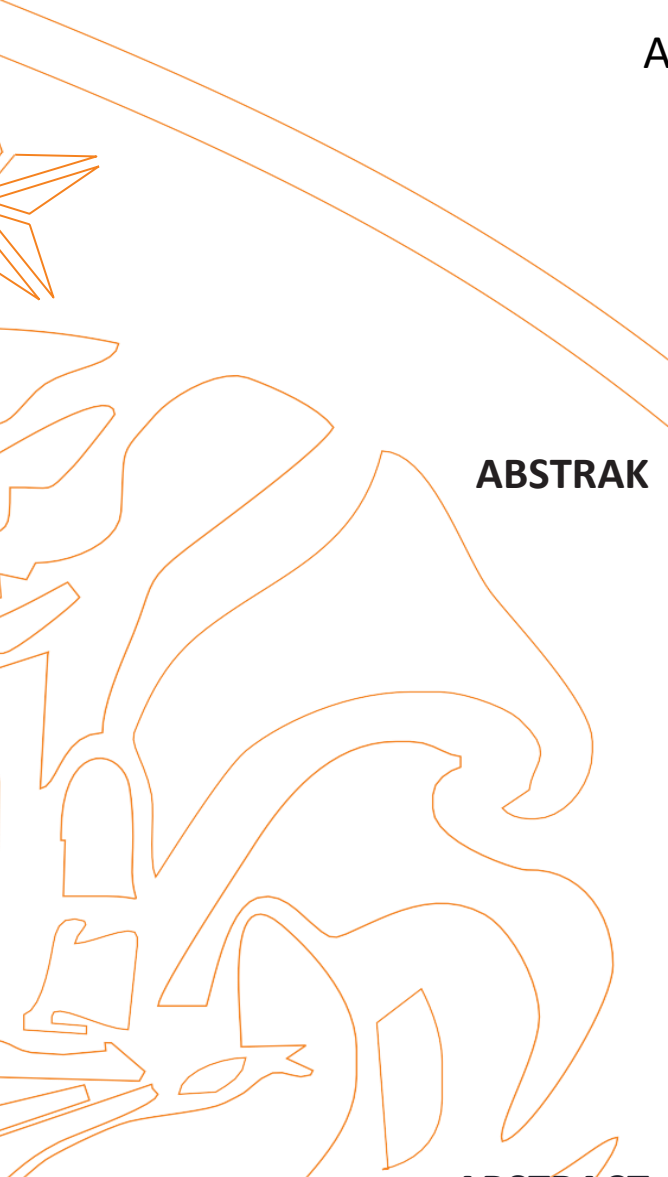

ABSTRACT

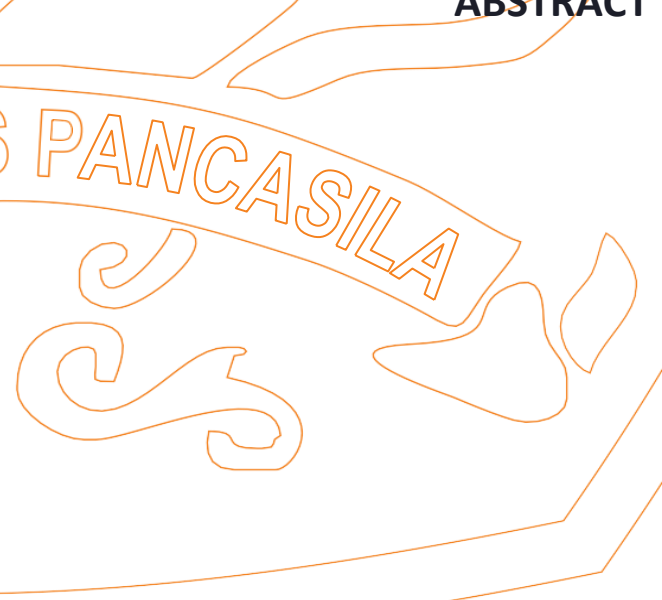

\author{
Alfito Deannova Ginting, Anna Agustina, \\ Dwi Salfiani, dan Fidel Muhamad Isra \\ Fakultas Ilmu Komunikasi, Universitas Pancasila \\ alfitodeannova@univpancasila.ac.id
}

\begin{abstract}
The technology and implications of using technology that converts vertical structures into horizontals make the concept of journalism problematic in many ways. The business model of media organizations seen from the concept of media management in producing news and journalistic ethics are two topics that are always a discussion. This article describes both topics based on references to the concept of mass media management and elements of journalism and journalism ethics in the Indonesian Press Basic Law. The data collection techniques used are informant interviews and analysis of documents that develop on both topics. The analysis of both summarized data shows that the current media business model shifts from focusing only on data reporting to information, expanding into businesses that manage data and information from production, distribution, transmission, and publication lines.
\end{abstract}

Keywords: Bussines Model, Media Etic, Information Integration, Jurnalistic, Media Organizasition

Journal of Strategic

Communication

Vol. 11, No. 1, Hal. 12-18.

September 2020

Fakultas Ilmu Komunikasi, Universitas Pancasila 


\section{PENDAHULUAN}

Saat ini kita hidup dalam data dan informasi yang berlimpah. Tehnologi memberikan akses kepelbagai hal dalam satu waktu. Pilihan menjadi lebih banyak. Jurnalis yang selalu mencari data, dan informasi berdasarkan peristiwa tidak melulu harus turun ke lapangan untuk mendapatkan berita. Banyak informasi masuk ke dalam gadgetyang dapat diolah kembali menjadi berita dengan memperhatikan tempat, waktu dan nilai berita. Trend mengolah ulang informasi saat ini terjadi. Jebakannya berada pada kemahiran jurnalis dalam mengidentifikasi kebenaran informasi dan data yang diterima sebelum diolah kembali. Kemahiran jurnalis bukan saja dalam memilih dan memilah informasi dan data namun juga dituntut kemahiran menggunakan tehnologi pendeteksi data dan informasi.

Terintegrasinya tehnologi dalam pengelolaan media mengubah struktur organisasi media. Hal ini diasumsikan memberi pengaruh pada bisnis media dan pelaksanaan pengelolaannya. Sehingga asumsi berikutnya adalah perlu ada penyesuaian etika media dalam konteks bisnis yang berubah ini. Etika yang digunakan dalam mengevaluasi kinerja media dan jurnalisme saat ini lahir saat struktur masyarakat dan media bersifat vertikal. Ketika informasi yang ada di masyarakat menjadi benar adanya atau sah ketika organisasi media mengkonfirmasi informasi tersebut melalui terbitan tulisan jurnalis di media atau siaran di televisi dan radio. Organisasi media menjadi sumber utama informasi bagi masyarakat. Pesan yang dipublikasi oleh organisasi media menjadi sangat dipercaya, bahkan menjadi topik pembicaraan di masyarakat. Konteks ini yang terjadi di masyarakat sebelum munculnya jurnalisme warga, dan maraknya media sosial yang memberikan tempat bagi setiap individu untuk mengunggah informasi tentang berbagai peristiwa yang mereka temui dan alami.

Struktur vertikal media juga diartikan sebagai adanya hirarki pemangku kepentingan yang dapat memengaruhi isi berita. Negara, pemilik media, kepentingan kantor berita, editor dan jurnalisme menjadi para pemangku kepentingan yang terlibat dalam struktur media. Hirarki dalam organisasi media pada umumnya dimulai dari pemilik media yang memiliki wewenang tertinggi pada proses jurnalistik, lalu kepentingan media, pemimpin redaksi, editor, hinggaterendah ada pada reporter,individu yang menyaksikan langsung peristiwa di lapangan. Konteks ini menunjukkan bahwa penentu isi media berada pada pemilik media.Hal ini terus didiskusikan oleh Reese dalam penelitiannya sejak tahun 1981 ketika menulis tentang liputan politik dalam konteks munculnya internet, yang kemudian pada tahun 2001 struktur ini dikelompokkan menjadi 5 level hirarki oleh Reese dengan konteks hirarki yang selalu memberikan pengaruh pada proses jurnalisme di media. Isu ini juga dibahas dalam konteks Indonesia dengan temuan yang sama bahwa peristiwa yang benar terjadi di masyarakat dan dilaporkan oleh reporter kepada redaksi, bisa saja tidak akan muncul dalam media jika pemilik tidak mengijinkan, atau jika laporan reporter akan merugikan kepentingankepentingan pemilik media (Ross, 2010; Darmanto dan Rianto, ed., 2015).

Struktur media bersifat vertikal dalam masyarakat diartikan sebagai penguasa informasi adalah media dan konsumen informasi adalah masyarakat. Kajian-kajian yang menggunakan teori kultivasi, penggunaan dan kepuasan, jarum hipodermik adalah beberapa contoh yang menunjukkan bahwa informasi dalam masyarakat dan diserap oleh masyarakat adalah informasi yang dimunculkan oleh media. Media ditempatkan pada hirarki yang lebih tinggi dari masyarakat dalam hal menyampaikan informasi, sehingga untuk mengelola kekuasaan media agar tidak merugikan masyarakat Bill Kovach dan Rosenthiel menuliskan tentang elemen-elemen jurnalisme. Kesepakatan para jurnalis di seluruh dunia adalah proses jurnalistik yang baik dan benar adalah yang memenuhi memenuhi elemen-elemen jurnalistik. Jumlah elemen yang harus dipenuhi, sesuai dengan menyatunya tehnologi dalam jurnalisme juga berubah dari 9 elemen menjadi 10 elemen sesuai dengan kajian Kovach dan Rosenthiel. Di Indonesia proses jurnalisme selain mengikuti elemen jurnalisme tersebut juga dibakukan dalam bentuk undang-undang Pokok Pers yang ditetapkan oleh pemerintah dan kode etik jurnalistik yang dibakukan oleh para pemangku kepentingan dalam bidang jurnalistik.

\section{TINJAUAN PUSTAKA}

Konteks media sangat berkuasa, berubah drastis ketika internet, tehnologi, dan media sosial menyatu dalamorganisasi media.Bukan saja organisasi media yang memiliki surat ijin terbit yang dapat memberikan informasi kepada masyarakat. Setiap individu dapat memberikan informasi melalui akun media sosialnya masing-masing secara langsung ketika melihat suatu peristiwa, bahkan saat ini peristiwa yang banyak diunggah dalam media sosial dapat mempengaruhi pemilihan topik headline media arus utama.Hal ini menunjukkan bahwa, media arus utama yang dikenal terdiri dari media cetak, media radio, dan media televisi terdesak untuk berubah menjadi online atau mengembangkan diri dengaan menambah media online ketika internet dan media sosial menyatu dalam organisasi media dan proses jurnalistik. 
13| CoverAge, Vol. 11, No. 1, September

Perkembangan organisasi media di Indonesia terjadi pada tahun 1998. Tahun dimana pers bisa menikmati kebebasannya tanpa dikontrol pemerintah, dan penerbitan media tidak lagi perlu lisensi dari pemerintah (1). Sejak tahun 1998, banyak sekali terbit media baru. Lim (2012), Nugroho, dkk. (2012), dan Haryanto (dalam Sen dan Hill, 2011) mendata media cetak berjumlah 1076 media, radio 2800 stasiun, dan stasiun televisi sejumlah 11 . Pemilik ribuan media tersebut digambarkan oleh Nugroho, dkk. (2012) dan Lim (2012) berpusat pada 12 hingga 13 kelompok pemilik media di Indonesia yang hingga saat ini masih berkuasa. Indikator ke (2) konvergensi di Indonesia adalah diadopsinya tehnologi telekomunikasi oleh para pemilik media di Indonesia. Dorongan untuk mendapatkan keuntungan yang lebih banyak dari memanfaatkan tehnologi serta kerjasama dalam berbagai lini bisnis (Agustina, 2018) mendominasi pertimbangan pemilik media dalam mengembangkan industri media di Indonesia.

Kentalnya perspektif bisnis, masuknya tehnologi yang mendukung peningkatan ekonomi media, serta dibukanya kepemilikan media tanpa surat ijin dari pemerintah mendorong banyak perubahan dalam lansekap media di Indonesia. Perubahan pemilik media yang awalnya hanya dimungkinkan oleh korporasi besar, kini individu pun dapat memiliki media. Hal ini dapat dilihat dari adanya pemilik media baru yang muncul di level lokal seperti di Bali, dan di Cirebon (Ri'aeni dan Sulistiana, 2017). Perubahan lain yang juga terlihat adalah adanya perubahan format dan disain surat kabar di indonesia (Ruswandi 2006), juga terjadinya penggabungan redaksi dari beberapa media seperti yang dilakukan oleh Tempo (Pratopo, dff. (2018). Perubahan-perubahan tersebut tidak bisa dihindari karena tehnologi telah masuk dalam organisasi media dan tuntutan merampingkan organisasi menjadi pertimbangan penting dalam konteks manajemen media. Lalu bagaimana dengan isi media dan etika yang mendampinginya? Kajian yang mempengaruhi isi media telah dilakukan sejak lama dan konsep penting yang selalu menjadi rujukan adalah kajian Shoemaker dan Reese (1996).

Shoemaker dan Reese (1996) memaparkan bahwa faktor-faktor yang mempengaruhi isi media dalam konteks organisasi media terdiri dari lima level yang diawali dari level individu, kemudian level hubungan media/redaksi, lalu level organisasi media, level pemilik media, hingga pada level ideologi.
Alfito Deannova Ginting et.al

Level 5: Ideologi media (nasional/internasional)

Level 4: Ekstramedia - kebijakan holding

\begin{tabular}{l|c}
$\begin{array}{l}\text { Hirarki } \\
\text { pengaruh } \\
\text { isi media }\end{array}$ & Level 3: Organisasi media - kebijakan pemilik \\
& Level 2: Rutinitas redaksi - kebijakan redaksi \\
\hline & Level 1: Individu - kebijakan jurnalis/editor \\
Gambar 1. Level Hirarki Pengaruh Isi Media Shoemaker dan \\
Reese (1996)
\end{tabular}

Manajemen media massa dalam berbagai konteks tetap perlu memperhatikan beberapa hal penting dalam mengelola entitas media. Eni Maryani, seorang dosen senior FIKOM Universitas Padjajaran dalam materi perkuliahannya menyatakan bahwa faktor penting dalam mengelola media yang profesional terdiri dari: investasi, sumber daya manusia, perkembangan tehnologi, pertimbangan ekonomi, dan regulasi media. Media tidak dapat berdiri hanya dengan modal idealisme, ia harus memiliki modal yang cukup untuk melakukan proses produksi. Selain itu media juga perlu memiliki sumber daya manusia (SDM) yang merupakan kekuatan besar dalam institusi media yang merupakan komponen utama dan penting dalam meletakkan konteks isu/peristiwa/data dalam media baik dengan proses produksi jurnalisme yang seratus persen menggunakan manusia maupun proses produksi jurnalisme yang melibatkan robot dalam menulis berita. Faktor penting ketiga dalam manajemen media massa adalah tehnologi yang digunakan oleh media dalam melakukan proses produksi berita dimana masyarakat terlibat di dalamnya, serta hal-hal yang dituliskan Shoemaker dan Reese juga masih berjalan. Faktor penting berikutnya adalah faktor kesadaran media sebagai salah satu entitas ekonomi di masyarakat. Media perlu sadar bahwa ia menjadi salah satu entitas ekonomi di masyarakat dalam konteks dimana organisasi media juga memerlukan investasi dan sumber daya dalam menyampaikan informasi yang orientasinya berpihak pada kepentingan orang banyak. Media tidak lagi bisa hidup hanya dalam idealisme. Saat ini dukungan ekonomi juga diperlukan untuk menjaga eksistensi media namun media tetap harus memiliki idealisme dan menyampaikan kebenaran pada masyarakat karena ideologi media tidak berubah dalam kondisi apapun. Hal ini kemudian diperlukan dukungan dari regulasi media yang menjadi faktor terakhir dari manajemen media massa. Regulasi media merupakan hal penting bagi pihak media karena regulasi memberikan batasan media untuk bisa berkembang dan menentukan tugas pokok fungsi antar warga negara mengingat undang-undang diciptakan untuk menjaga keharmonisan warga negara. 
Undang-undang Pokok Pers yang menjadi pedoman proses jurnalistik di Indonesia memiliki nilai-nilai universal jika diperhatikan dengan merujuk ada elemen jurnalisme yang dikeluarkan oleh Bill Kovach dan Rosenthiel. Elemen jurnalisme yang diakui untuk diterapkan pada saat melakukan proses jurnalistik bukan saja pada level national namun juga pada level global. Elemen jurnalisme yang ada dan tercermin dalam UU Pokok Pers dan elemen-elemen jurnalisme yang selalu menjadi perhatian jurnalis seluruh dunia antara lain adalah memiliki idealisme berjuang untuk kepentingan masyarakat di atas kepentingan kelompok, melakukan cek dan re-check dalam setiap informasi dan peristiwa yang diterima jurnalis, memperhatikan keseimbangan informasi dari pihakpihak yang terlibat dalam peristiwa yang diliput, jurnalis melaporkan peristiwa berdasarkan fakta, dan tidak boleh memberikan opini dalam informasi yang diproduksi sebgai berita.

Kajian terkait etika jurnalisme dalam masa berkembanganya media online banyak dilakukan bukan saja di Indonesia, namun juga di berbagai negara. Jurnalisme online dituliskan oleh Musman (2017) diakui berkembang ketika skandal Monicagate muncul di Amerika Serikat pada tahun 1998 yang ditulis di Drudge report. Tahun yang sama, di Indonesia terjadi peralihan pemerintahan dari orde baru ke orde reformasi. Peristiwa ini dianggap sebagai salah satu tanda berkembangnya jurnalisme online di Indonesia yang memiliki dampak media yang sama kuat dengan media mainstream karena informasi di media sosial memiliki kontribusi pada pengumpulan opini massa dan menciptakan pergerakan yang memiliki dampak terjadinya pergeseran kepemimpinan bangsa. Hal serupa dianggap juga terjadi pada ksus yang dikenal dengan Arab Spring. Rentang saktu ini menjadi tanda berkembangnya jurnalisme online yang dalam proses jurnalistik beberapa elemen jurnalisme diabaikan. Konten peristiwa yang muncul dalam media sosial benyak yang berupa opini, tiak mementingkan proposionalitas pemangku kepentingan dalam isu yang ditampilkan. Pro-kontra tentang isi media sosial adalah jurnalisme atau tidak kemudian berkembang. Alhasil muncul istilah baru dalam jurnalisme seperti, jurnalisme warga, jurnalisme data, dan jurnalisme advokasi. Kemunculan istilah baru dalam jurnalisme ini diikuti dengan beberapa perubahan lain yang salah satunya disain media, disain kepemilikan, disain penyebaran informasi yang telah diproduksi oleh media dalam kepemlikan yang sama, yang jika dilihat dari etika dan elemen jurnalisme tidak lagi memenuhi. Banyak berita yang melibatkan tehnolog dinyatakan melanggar lelemn jrunalisme dan tidak etis.

Diskusi adanya perubahan struktur media yang perlu diikuti dengan perubahan etika dan elemen jurnalisme menjadi diskusi yang terus bergulir. Di negara maju kajian tentang hal ini telah banyak dilakukan, namun di indonesia keterkaitan dengan struktur danmodel bisnis belum dilakukan, sehingga hal ini yang diharapkan muncul dalam hasil dari kajian dan dipaparkan dalam artikel ini.

\section{METODE}

Artikel ini menggunakan teknik pengumpulan data studi dokumen dan wawancara mendalam untuk mencari jawaban dari apa yang terjadi pada model bisnis organisasi media, dan untuk mengidentifikasi etika yang berlaku dalam konteks dimana tehnologi menjadi bagian penting dalam organisasi media dan dalam memproduksi berita. Pendekatan kualitatif dengan disain riset eksploratif ini menggunakan teknik analisis data post positivis. Pandangan Shoemaker dan Reese, yang sangat terkenal diterbitkan pada tahun 1966, tentang produksi berita menjadi acuan dalam melihat proses produksi dalam organisasi media yang dalam artikel ini diasumsikan menentukan model bisnis media. Elemen jurnalisme dan kode etik jurnalistik yang ditetapkan dalam UU Pokok Pers Indonesia menjadi acuan dalam mengkaji etika jurnalistik yang berlaku dimana media saat ini tidak lagi menjadi sumber utama informasi bagi masyarakat.

\section{HASIL DAN PEMBAHASAN}

\section{Model bisnis organisasi media}

Bisnis organisasi media dikatakan berhasil jika lebih dari 50\% proses produksi media expenses berasal dari iklan media. Menurut para informan, yang saat ini menduduki posisi editorial, persepsi ini menjadi pegangan organisasi media sejak media menjadi industri, dimana bisnis sudah masuk dalam pertimbangan penting dalam mengelola organisasi media. Hal ini menjadi tantangan tersendiri bagi organisasi media di Indonesia yang sejarah pendiriannya bukan berdasarkan perhitungan bisnis, namun berdasarkan idealisme.

Perkembangan mediadi Indonesia, berawal bukan dari pertimbangan bisnis, namun dari pertimbangan idealisme para pejuang yang bersatu untuk mendorong tercapainya kemerdekaan. Para pejuang kemerdekaan ini menggunakan media untuk berkirim pesan dalam rangka kordinasi untuk pergerakan. Sumber daya diberikan oleh para pejuang dan semua yang terlibat untuk tujuan yang sama tanpa berpikir untung rugi. Produksi, distribusi, dan publikasi dilakukan oleh orang yang sama. Sumber daya yang digunakan dan terlibat semua dari pihak yang sama untuk satu tujuan bersama. Hal ini menunjukkan tidak adanya pembagian tugas antara pengelola bisnis media dan produksi berita. Semua dilakukan bersama berdasarkan tujuan yang sama, mencapai 
kemerdekaan indonesia. Model pengelolaan organisasi media seperti ini tidak bisa lagi dilakukan ketika media telah menjadi industri.

Setelah Indonesia merdeka, masa orde lama, banyak media tumbuh yang dikelola oleh kelompok yang memiliki kepentingan yang sama. Tumbuhnya media tidak memerlukan ijin dari pemerintah yang baru dan berdaulat. Para pemilik media menuangkan visi dan misi serta kepentingan kelompoknya dalam konten media yang mereka kelola (Wiratraman, 2014; Kakiailatu, 2007). Informan juga menjelaskan organisasi media masa orde baru sesuai dengan hasil temuan dalam dokumen tersebut. Di masa orde lama semua kelompok atau individu dapat membuat mediia dengan modal sendiri atau kelompok. Konten media sangat beragam tergantung dari kelompok yang mengeluarkan media tersebut. Informasi dalam media sangat mementingkan kelompok. Menurut informan yang sangat senior dan saat ini aktif di lembaga yang menyelenggarakan pendidikan jurnalistitk di Jakarta, media masa orde lama digunakan untuk memberikan informasi dan merekrut masyarakat untuk masuk dalam kelompok yang saat itu banyak sekali pilihannya dan berupa organisasi politik atau keagamaan. Organisasi media lainnya yang kemudian muncul adalah media yang dimiliki dan dikelola oleh pemerintah. Namun selang beberapa tahun setelah merdeka, mulai muncul pengelolaan bisnis media yang berorientasi bisnis dan memerlukan surat ijin dari pemerintah. ljin terbit yang wajib dimiliki media membatasi gerak bisnis media di Indonesia. Di sisi lain media dikelola sebagai bisnis telah muncul yang ditandai dengan adanya iklan yang masuk dan muncul di halaman koran. Iklan juga menjadi salah satu pos pendapatan dari proses produksi koran saat itu selain dari tiras penjualan.

Bisnis media masa orde lama masih bergabung antara pemilik, pengelola media, dan pengurus iklan yang masuk. Meski pembagian kerja mulai terjadi beberapa tahun kemudian. Bagian pencari iklan, bagian pembelian kertas dan tinta, bagian penjualan koran, dan bagian redaksi. Profesionalisme ini makin berkembang di masa orde baru. Profesionalisme yang diterapkan dalam pengelolaan yaitu bagian menajerial dan bagian redaksi yang terpisah sehingga berita dan proses jurnalistik tidak dipengaruhi oleh pengiklan. Kerjasama yang terjadi antara organisasi media dalam bisnisnya diatur oleh bagian bisnis media bukan oleh redaksi. Beberapa media besar melakukan hal ini, namun di daerah bisnis media meski tetap diusahakan profesional namun tetap dalam beberapa kasus jurnalis pun diminta mencari iklan.

Perusahaan yang produknya akan diiklankan di koran akan berinteraksi dengan bidang iklan dan usaha organisasi media. Saham media dikelola sendiri oleh media bahkan $20 \%$ nya dimiliki oleh jurnalis. Ini masa keemasan media sebagai bisnis di Indonesia. Jurnalis memiliki saham dari medianya yang dikelola dengan profesional. Jadi ketika media untung jurnalis mendapat keuntungan, dan juga sebaliknya.

Perkembangan yang ada dalam bisnis media ketika telekomunikasi dan internet terintegrasi dalam proses jurnalistik adalah berubahnya struktur organisasi media dan peran media. Produksi konten atau informasi atau berita menjadi terpisah dari transmisi dan distribusi. Keberhasilan media tidak lagi hanya dihitung dari tiras penjualan, atau jumlah penonton atau pendengar, namun juga dari yang di klik oleh masyarakat. Bisnis media kemudian dimiliki oleh gabungan pengusaha yang memiliki organisasi media, organisasi provider telepon, dan organisasi provider gadget. Kerjasama ketiga perusahaan ini kemudian bukan saja mempengaruhi proses jurnalistik, juga menimbulkan semakin banyak kepentingan dala melaporkan peristiwa kemasyarakat mengingat kepentingan yang diampu oleh proses jurnalistik dari peristiwa yang ada di masyarakat semakin luas. Pemangku kepentingan media semakin besar dan semakin beragam, pemiliki media, pemilik bisnis telekmunikasi dan perusahaan gadget (Agustina, 2018).

Media indonesia sejak mengintegrasikan beberapa platform medianya menambahkan tim IT dalam jajaran redaksi. Tempo media mendorong bisnis medianya dengan model menggabungkan redaksi untuk beberapa platform media. Beberapa media besar di Indonesia melakukan penggabungan redaksi nya seperti Tempo media dalam menjaga eksistensi bisnis medianya. Tribun, Jawa Pos, MNC, Emtek, Transmedia, dan Kompas adalah beberapa organisasi media yang model bisnisnya berubahsecara struktur dan kepemilikan, mengikuti perkembangan tehnologi telekomunikasi dan internet, serta perilaku masyarakat. Orientasi bisnis media yang bekerjasama dengan beberapa perusahaan lain terkait tehnologi dan telekomunikasi menjadi salah satu bentuk baru model bisnis media.

Perubahan model bisnis media dapat ditandai dari beberapa faktor, yaitu perubahan adanya atau tidak adanya surat ijin bisnis media dari pemerintah, perubahan struktur pemilik saham dari pengusaha media yang kini melibatkan provider telepon dan pengusaha telekomunikasi, dan perubahan stuktur di dalam organisasi media, yang awalnya redaksi dan manajemen terpisah antara majalah, koran dan online media,menjadi terintegrasinya redaksi untuk seluruh template media, lalu adanya tambahan tim IT untuk menyesuaikan dengan beragam template media utama dan media sosial, serta perubahan perilaku masyarakat dalam mengkonsumsi konten media dan informasi. Semua faktor ini yang 
mendorong terjadinya perubahan model bisnis media. Faktor yang mempengaruhi isi konten media tetap sama seperti pada level yang kelompokkan oleh Reese, bahkan level extra media bukan lagi pada holding namun pada pemilik saham organisasi media.Pihak yang mempengaruhi konten media lebih luas hingga lini bisnis yang saat ini menjadi penting bagi distribusi dan transmisi berita ke masyarakat dimana klik menjadi salah satu pos pendapatan dari bisnis media. Kompetitor bisnis media juga bukan hanya media lain, namun juga individu yang memiliki banyak pengaruh pada masyarakat. Belakangan ini diskusi tentang kompetisi iklan di media dan influencer mengemuka. Hal ini menandakan model bisnis media benar-benar berubah. Bagaimana dengan konten yang muncul di media? Milik siapa konten tersebut dan bagaimana etikanya? Berikut adalah hasil dari wawancara informan dan data dari dokumen yang membahas etika bermedia terkait konten.

\section{Etika Media}

Diskusi tentang etika menurut beberapa informan menjadi kabur antara etika profesi, etika media, atau etika konten media. Jika etika dimaknai dengan apa yang boleh dan tidak boleh muncul di beragam platform media, maka sudah ada peraturan yang menjelaskan hal ini. Banyak peraturan yang menetapkan apa yang boleh dan tidak boleh dalam mengisi beragamnya media saat ini. UU Pokok Pers, UU penyiaran, UU Periklanan, adalah beberapa aturan yang telah menetapkan apa yang boleh dan tidak boleh ditampilkan dalam media. Ada lagi UU ITE, yang juga mengatur apa yang boleh dan tidak boleh muncul dalam media. Para informan memiliki pandangan yang sama bahwa semua peraturan ini disahkan dalam rangka menjaga etika media dalam menampilkan kontennya.

Para informan (MNC, Lokadata, Republika, Detik) cenderung memberikan pendapat bahwa peraturan yang ada tersebut sebenarnya juga telah mengatur etika profesi, etika media dan etika konten media. Etika yang ada telah sesuai dan cukup untuk mengatur apa yang harus dilakukan. Mereka memberikan gambaran bahwa apa yang benar atau salah sepanjang hidup akan tetap sama pedomannya, sehingga etika itu tidak perlu lagi berubah-ubah mengikuti zaman. Hanya perlu menerjemahkan pelaksanaannya dalam konteks masing-masing era dan organisasi. Salah satu informan menjelaskan bahwa dari dulu hingga kini kalau kita menggunakan hasil karya orang lain, kita tidak boleh mengaku kalau itu hasil karya kita. Jadi kita perlu informasikan ke publik karya siapa yang kita rujuk. Lalu beberapa informan memberikan perspektif pentingnya mendahulukan kepentingan kelompok yang lebih besar dengan gambaran bahwa kerja media itu berinteraksi dengan orang banyak, dan ketika berinteraksi kita semua pastinya berharap dapat memberikan kontribusi yang baik dan positif bagi masyarakat, makanya informasi yang diterbitkan adalah informasi yang dapat memberikan manfaat bagi masyarakat banyak. Salah satu caranya dengan memberikan informasi yang benar dari sumber yang pertama.

Informan dari Lokadata menyatakan bahwa pelanggaran etika kadang berawal dari ketidakpahaman level atau sturktur nara sumber. la menjelaskan bahwa, dalam struktur nara sumber, yang pertama itu adalah mereka yang memang terlibat dalam peristiwa, first hand news source seperti pelaku dan korban. Jika peneliti berarti yang melakukan penelitian, dan telah memiliki porto folio tentang penelitian yang sama, sehingga dapat memberikan data hasil penelitiannya. Struktur nara sumber yang kedua adalah mereka yang terlibat, dan memiliki wewenang dalam peristiwa, misalnya saksi peristiwa, polisi, rumah sakit, kantor dinas pemerintah, atau kantor pemerintah lainnya. Struktur nara sumber ketiga adalah pakar atau ahli dalam peristiwa yang terjadi, sehingga pendapatnya bisa dipertanggungjawabkan melalui latar belakang pendidikan atau porto folionya. Struktur nara sumber ke empat itu yang memberikan komentar, misalnya pernyataan simpati dari kerabat atau kawan.

Saat ini, etika kadang tidak diperhatikan karena para pelaksana penyampai informasi tidak paham dengan struktur nara sumber tersebut. Nara sumber level ke empat tiba-tiba dikutip pesannya, padahal nara sumber pertama, kedua dan ketiga belum ada. Sehingga, kesannya adalah siapa saja bisa kasih komentar dan bila yang berkomentar itu banyak followernya, langsung ditayangkan atau dikutip tanpa memperhatikan konteks, padahal banyak follower belum tentu terkait dengan peristiwa yang terjadi. Hal ini kemudian menyebabkan masalah etika. Di Indonesia, permasalahan etika ini melibatkan masyarakat atau sumber yang ada dalam berita, media yang menerbitkan berita, dan dewan pers. Kasus-kasus yang ditangani oleh Dewan Pers masuk dalam kasuskasus etika yang rujukannya adalah UU Pokok Pers dan Etika jurnalisme di Indonesia. Hingga kini, persoalan etika di indonesia masih dalam konteks ini. Konteks kesalahan tulisan dalam berita yang muncul di media, kemudian jika diadukan oleh masyarakat ke dewan pers, maka hal ini menjadi kasus etika jurnalisme. Jika masyarakt tidak mengadu, maka tidak menjadi kasus etika. Mekanisme ini masih berlaku di indonesia, dan masih belum diusulkan untuk dimutakhirkan dalam konteks dimana tehnologi terintegrasi dalam kehidupan individu, organisasi media, dan proses jurnalistik. Undang-undang yang berkembang seiring dengan terjadinya pelanggaran karena adanya 
17| CoverAge, Vol. 11, No. 1, September

integrasi tehnologi dalam proses jurnalistik, kemudian mengarah bukan lagi pada etika namun pada tindakan kriminal. Konsekuensinya adalah adanya undang-undang Informasi, tehnologi dan elektronik yang mengatur apa yang boleh dan tidak boleh dalam konten di jejaring media. Undangundang memiliki konsekuensi hukum positif sehingga bukan lagi dalam area etika. Para informan menyatakan bahwa konten di media berjejaring dan proses jurnalistik dalam media berjejaring terus dan masih menjadi perdebatan yang indikasinya terlihat pada adanya diskusi yang ramai terjadi di masyarakat ketika UU ITE ini diberlakukan. Pada kasus Prita, sebagai contoh, masyarakat malah memberikan alternatif solusi dari keputusan UU yang ditetapkan. Hal ini mengindikasikan bahwa sebenarnya masih ada protes dari masyarakat bukan saja jurnalis, tentang ditetapkannya UU ITE pada informasi di media berjejaring. Perspektif ini sama dari semua informan.

Terkait terintegrasinya beberapa platform media dalam satu redaksi, para informan memberikan pandangan tentang etika melalui pentingnya sosialisasi budaya organisasi serta visi misi organisasi. Jurnalis perlu memahami perubahan aturan main ketika koran bergabung dengan online jika sebelumnya terpisah kemudian bergabung, atau koran daerah yang awalnya milik sendiri lalu berubah dimiliki juga oleh pemilik koran di Jakarta, atau awalnya milik sendiri lalu berubah ada perjanjian dengan perusahaan baru penyelenggara provider atau produsen gadget. Etikanya tetap perlu memberi informasi lebih dulu. Pertama, memberi informasi tentang budaya organisasi yang baru, lalu kedua memberi informasi kepada jurnalis yang menulis berita bahwa tulisannya akan dimuat di media apa saja, ketiga jika dituliskan kembali, maka menuliskan sumber pertama yang menjadi rujukan di media berikutnya meski dalam pemilik yang sama. Dalam konteks ekologi produksi dan konsumsi berita yang ada saat ini, seperti yang dikatakan oleh Newsman, dkk. (2012), ada peran ganda antar individu, kelompok, media, dan antar media sehingga dianggap sudah transparan dan antar dunia selalu terkoneksi. Namun pada prakteknya rujukan etika yang disampaikan oleh para informan tetap seperti etika dimana terbatas pada elemen jurnalisme dan UU Pokok Pers Indonesia.

Rincian pelaksanaan etika ini kemudian kembali kepada perlunya informasi berimbang, dan ijin jurnalis sebelum organisasi media menerbitkan tulisan jurnalis kembali di media lainnya tanpa merujuk pada media pertama yang telah menerbitkannya lebih dulu. Etika yang baik dalam organisasi media diusulkan informan untuk dikomunikasikan pihak organisasi media kepada karyawannya termasuk jurnalis, sehingga jurnalis
Alfito Deannova Ginting et.al paham tulisannya ada di media apa saja untuk bisa bertanggungjawab atas tulisan tersebut. Sementara informan lain menyampaikan bahwa etika terkait ijin menerbitkan tulisan jurnalis, saat ini sudah tidak jelas karena banyak praktek yang dilakukan jurnalis adalah menuliskan berita serupa untuk beragam media dan antar jurnalis tidak ada yang merasa keberatan,meski dari media yang berbeda tidak dalam satu grup holding, sehingga pengelola organisasi media menganggap jika dalam satu holding hal ini pun tidak terkait etika.

Pendapat berbeda antar dua informan ini memberikan gambaran bahwa etika rinciannya sangat beragam ketika tiba pada praktek proses jurnalistik. Ekologi baru jejaring individu dan institusi media yang digambarkan oleh Newman, dkk. (2012) di Inggris juga menyinggung perlunya pertimbangan dan diskusi terkait etika dalam mengevaluasi ekologi baru tersebut. Demikian juga dalam konteks jurnalistik, etika jurnalistik dalam konteks baru dimana individu dan media berjejaring perlu didiskusikan kembali.

\section{SIMPULAN}

Berkembangnya tehnologi yang kemudian terintegrasi dalam kehidupan individu dan juga institusi mendorong terjadinya perubahan di berbagai segi, termasuk model bisnis media. Bergesernya model bisnis media kemudian juga mendorong adanya diskusi terkait apa yang dikatakan etis dan tidak etis. Dilihat dari level hirarki yang mempengaruhi berita, terlihat bahwa level yang memberi pengaruh pada produksi dan distribusi berita adalah sama, namun cakupan pada level extra media menjadi lebih luas akibat organisasi pemilik media kemudian berjejaring ke perusahaan-perusahaan yang lebih beragam. Pemilik saham organisasi media menjadi lebih luas, bukan saja jurnalis, holding pemilik media, tetapi juga produsen atau perusahaan yang memproduksi gadget, dan penyedia paket data atau perusahaan telekomunikasi, sehingga level etra media mejadi lebih luas. Implikasi dari berkembangnya cakupan yang lebih luas adalah munculnya banyak kepentingan baru yang kemudian perlu dipertimbangkan oleh level rutin ataupun level jurnalis.

Implikasi baru yang juga menjadi perhatian para peneliti komunikasi adalah dalam konteks individu dan media berjejaring dalam memproduksi berita dan mengkonsumsi media, maka perlu dipikirkan kembali etika media, individu, dan etika jurnalistik. Hasil dari kajian ini, data dokumen kajian etika di Indonesia masih mengacu pada etika jurnalistik yang sesuai dengan elemen jurnalisme dan UU pokok Pers. Para informan yang memiliki profil jurnalist senior memiliki perspektif yang cenderung sama, yaitu etika 
profesi jurnalist tetap masih sama dengan sebelumya karena profesi jurnalis tetap perlu mengacu pada perlunya memperjuangkan kepentingan yang lebih besar, keseimbangan informasi, serta pentingnya konfirmasi informasi (check-re-check). Hal baru yang muncul terkait etika adalah perlunya sosialisasi tentang budaya organisasi yang baru ketika organisasi media merubah struktur organisasinya. Kajian berikutnya perlu dilakukan model bisnis media yang sesuai dengan konteks individu dan media berjejaring dalam proses produksi dan konsumsi yang merupakan ekologi baru media. Lansekap media di Indonesia yang cenderung pada oligopoli serta konglomerasi (Lim, 2012; Nugroho, 2012) merupakan tantangan bagi kajian berikutnya pada model bisnis dan etika media.

\section{DAFTAR PUSTAKA}

Darmanto dan Rianto, Editor, (2015). Media Terpenjara Bayang-bayang Pemilik dalam Pemberitaan Pemilu 2014, Perkumpulan Masyarakat Peduli Media (MPM) Yogya dan Yayasan Tifa, Jakarta.

Kakiailatu, T. (2007). Media in Indonesia: Forum for political change and critical assessment. Asia Pacific Viewpoint, 48(1), 60-71.

Lim, Merlyna. (2012). The league of Thirteen: Media concentration in Indonesia. USA: Media Lab Arizona State university Tempe, Arizona US, The Ford Foundation.

Lim, M. (2011). @crossroads: Democratiozation \& corporatization of media in Indonesia.

Maryani, Eni. (2011). Materi Kuliah Manajemen Media, Program Pasca Sarjana Universitas Padjadjaran, Materi tidak dipublikasikan.

Murpidi S.R., and Madasamy, S. (2012),

"Mediascapes: Indonesia", Asian

Communication Book, $6^{\text {th }}$ edition, Asian Media Information and Communication Center, Singapore, p. 240.

Musman, A. M., (2017). Jurnalisme Dasar Panduan Praktis para jurnalis, PT. Anak Hebat Indonesia. Jakarta.

Newman, N., Dutton, W. H., dan Blank, G., (2012). Social media in the changing ecology of news: The fourth and fifth estates in Britain, International Journal of Internet Science, Vol. $7(1)$, p. 6-22.

Nugroho, Y., (2012). Mapping the landscape of the media industry in Contemporary Indonesia. Report Series: Engaging Media, Empowering Society: Assessing Media Policy and Governance in Indonesia through the Lens of Citizen's Rights. Jakarta CIPG, Ford Foundation, Jakarta.
Pergeseran Model Bisnis Media dan Etika Media: ... 118

freedom in Indonesia, conference paper, presented in Biennial Conference of the Asian Studies Association of Australia, 5-8 July, Adelaide.

Ross, T. (2012). Old Tricks in a new era: self censorship in Indonesian journalism, Asian Studies Review, 36:2, 227-245.

Ryfe, D. M. (2009). Broader and deeper: a study of newsroom culture in a time of change, Journalism, Vol. 10(2): 197-216

Reese, S. D. \& Miller, M., M. (1981). Political Attitude Holding and Structure: The Effects of Newspaper and Television News.Communication Research--An International Quarterly, Vol.8 (2), p.167-88.

Reese, S. D. (2001). Understanding the global journalists: a hierarchy-of-influences approach, Journalism Studies, Vol. 2(2), p. 173186

Reese, S. D., 2016, The New Geography of Journalism Research, Digital Journalism, Vol. 4 (7). https://doi.org/10.1080/21670811.2016.1 $\underline{152903}$.

Wirataman, H. P. (2014). Press freedom, law and politics in Indonesia: a socio-legal study. from Leiden University http://hdl.handle.net/1887/30106 